\title{
STUDENTS FEEDBACK ABOUT LECTURE ROOMS TO IMPROVE THE EFFECTIVENESS OF THE LECTURES
}

Sofia Shehzad ${ }^{1}$, Zainab Waheed ${ }^{2}$, Samir Khan Kabir ${ }^{2}$, Sofia Haider Durrani ${ }^{1}$, Muhammad llyas ${ }^{1}$, Afaq Farooq ${ }^{1}$

1. Gandhara University Peshawar

2. Sardar Begum Dental College

ABSTRACT: OBJECTIVES:

The study aim was to determine the feedback regarding the environment, satisfaction and further needs for modification in improving the effectiveness of the lecture.

\section{METHODOLOGY:}

It was a cross-sectional study to measure the student's feedback about lecture rooms to improve the effectiveness of the lectures. A questionnaire was designed to assess the student's response about the environment of the lecture room, the learning experience of the students, needs of other lecture rooms' modification, seating design and temperature of the lecture room. The total numbers of the participants were 115 students including both genders from Sardar Begum Dental College, Peshawar. Second-and fourth-year professional students were excluded from the study. Responses were recorded from 115 participants of the first- and third-year students of BDS. The obtained data were analyzed using SPSS 20.

\section{RESULTS:}

This study results showed that $100 \%$ of the students were satisfied with the environment of the classroom, to improve the learning experience $98 \%$ of the students were detected, $91 \%$ of students required modification of lecture rooms. $47 \%$ of the students preferred chairs with tables, $40 \%$ bench with tables and $11 \%$ are satisfied with the current setup. Twenty-four per cent of students suggested heaters in the lecture room during winter, $1.7 \%$ required air condition and $35 \%$ of students were satisfied with the room temperature. $38 \%$ of the students were satisfied with the effectiveness of the lectures.

\section{CONCLUSION:}

Students' feedbacks were satisfactory and it enhanced their learning experience. Students preferred the change in the seating design, chairs with tables.

KEYWORDS: Learning Experience, Lecture Room, Environment, Feedback, Modification

https://doi.org/10.37762/jgmds.6-1.88

\section{INTRODUCTION:}

Feedback refers to the opinions of students regarding the facilities they are receiving in an institute and about their learning experience. Educational institute facilities help the teachers to perform their duties effectively and enable learners to focus on their learning activities. The higher education institutes must execute a systematic approach for the maintenance of quality and standard of higher education through the feedback of the students. Shukla (2019) reported most of the feedback methods, to enhance the quality and standards of higher education ${ }^{1}$. In the $19^{\text {th }}$ century, it was uncommon to get feedback from the students about the lecture room infrastructure, satisfaction and their recommendations on it. But in the twentieth century, it is crucial to regulate and provide a satisfactory environment for the students, as it has an impact on the learning outcomes. Higher Education Commission in Australian universities concluded that there is a need for developing the evaluation framework and use of the student feedback for improvements ${ }^{2}$. Some of the facilities are essential for students in an educational institute, which are infrastructure and its modification, mode of teaching and facilities. Lecture room infrastructure and its environment have an important role to improve the learning experiences and enhance the performance of the students. A study was conducted to examine the seating time of the long lecture, the findings suggested to reduce the contact time of student-faculty to two-third to improve the outcomes ${ }^{3}$. According to the study, a well-ventilated room can improve student progress effectively ${ }^{4}$. In Steelcase study, students and faculty had more concentration in classrooms with new design than old traditional ones. For the healthy environment of the lecture rooms, encourages students to participate in classroom tasks effectively ${ }^{5}$ and give them opportunities to build social skills and strategies for effective learning outcomes ${ }^{6}$. According to Zifferblatt (1972) suggested a correlation between student behavior and furniture arrangement, creates a more open environment for students and encourage them to share their thoughts and ideas with peers ${ }^{7}$. 
Marchand et al (2014) studied the impact of lecture room infrastructure environment (lighting, sound and temperature) on the perception and learning of the students ${ }^{8}$. The high listening affected the efficacy of comprehension; the extreme condition affects the mood and reading condition having noise lead to a negative impact on the outcome. An ecological perspective was taken on learning, which helps us to understand the learner's spaces through their interactional activities. This study emphasizes to provide the relational and understanding of the learning spaces ${ }^{9}$. Therefore, students' feedback about the lecture rooms to improve the effectiveness of the lectures were designed i.e. learning environment, learning experience, need for other modifications, seating design and temperature. It is the first study conducted in the medical college of Peshawar, Khyber Pakhtunkhwa and its objective were to measure the student's feedback about the infrastructure/environment, seating design and temperature to improve the effectiveness of the learning process.

\section{METHODOLOGY:}

It was a cross-sectional study conducted at the Sardar Begum Dental College, Peshawar using both quantitative and qualitative approaches. The sample size was 115 students of BDS in the academic year of $1^{\text {st }}$ and $3^{\text {rd }}$ year professionals, including both genders. The $2^{\text {nd }}$ and $4^{\text {th }}$ year BDS students were excluded. It was a convenient sampling, a type of non-probability sampling. A close-ended questionnaire was designed. A pilot study was conducted on $10 \%$ of the population. $100 \%$ of the participants responded to the questionnaire. The approval for this study was taken from the ethical committee of Gandhara Medical University.

\section{RESULTS:}

115 students' feedbacks were used for the study to find the satisfaction of the students regarding lecture rooms' environment/infrastructure, learning experience, need for lecture rooms modification, seating design and temperature. Table 1 indicates the student's satisfaction about the lecture rooms' environment/infrastructure and its impact on learning experience. $100 \%$ of the students were satisfied with it and their learning experience was improved as well. Table 2 shows the need for further modifications, ninety-eight per cent students responded for further modifications in lecture rooms. Table 3 represents the seating design preferred by the medical students. $47.8 \%$ of the students preferred chairs with tables whereas $40.9 \%$ opted bench with tables. Table 4 indicates about the room temperature of the lecture rooms. For the thirty-eight per cent of the student's room temperature were acceptable while $24.3 \%$ of the students required heaters in the winter.

Table 1: Student's Satisfaction about the Lecture Room

\begin{tabular}{|c|c|c|c|c|c|c|}
\hline & & Frequency & Percentage & Mean & $\begin{array}{c}\text { Std. } \\
\text { Deviation }\end{array}$ & $\begin{array}{c}\mathrm{P}- \\
\text { value }\end{array}$ \\
\hline $\begin{array}{l}\text { Environment/ } \\
\text { infrastructure of the } \\
\text { class room }\end{array}$ & $\begin{array}{l}\text { Yes } \\
\text { No }\end{array}$ & $\begin{array}{c}100 \\
0\end{array}$ & $\begin{array}{c}100 \% \\
0\end{array}$ & .00 & .00 & 0 \\
\hline $\begin{array}{c}\text { Learning experience } \\
\text { improved }\end{array}$ & $\begin{array}{l}\text { Yes } \\
\text { No }\end{array}$ & $\begin{array}{l}98 \\
17 \\
\end{array}$ & $\begin{array}{l}85.2 \% \\
14.8 \% \\
\end{array}$ & .15 & .35 & 0.001 \\
\hline
\end{tabular}

Table 2: Need for Modifications

\begin{tabular}{|c|c|c|c|c|c|}
\hline $\begin{array}{c}\text { Need for Lecture Rooms } \\
\text { Modification }\end{array}$ & Frequency & Percentage & Mean & $\begin{array}{c}\text { Std. } \\
\text { Deviation }\end{array}$ & P-value \\
\hline Yes & 105 & $91.3 \%$ & .09 & .28 & 0.01 \\
\hline No & 10 & $8.7 \%$ & & & $0.01 \%$ \\
\hline
\end{tabular}

Table 3: Seating Design Preferences

\begin{tabular}{|c|c|c|c|c|c|}
\hline Seating Design & Frequency & Percentage & Mean & Std. Deviation & P-value \\
\hline Chairs with Tables & 55 & $47.8 \%$ & \multirow{4}{*}{.63} & \multirow{4}{*}{.68} & \multirow{4}{*}{0.01} \\
\hline Bench with Tables & 47 & $40.9 \%$ & & & \\
\hline Current Design & 13 & $11.3 \%$ & & & \\
\hline Total & 115 & $100 \%$ & & & \\
\hline
\end{tabular}




\begin{tabular}{|c|c|c|c|c|c|}
\hline $\begin{array}{c}\text { Temperature of } \\
\text { Classroom }\end{array}$ & Frequency & Percentage & Mean & Std. Deviation & P-value \\
\hline Heaters & 28 & $24.3 \%$ & & & \\
\hline A.C & 2 & $1.7 \%$ & & & \multirow{2}{*}{1.15} \\
\hline Satisfactory & 44 & $38.3 \%$ & & 0.02 \\
\cline { 1 - 3 } Total & 115 & $64.3 \%$ & & & \\
\hline
\end{tabular}

\section{DISCUSSION:}

This was a cross-sectional study conducted in the Sardar Begum Dental College, Peshawar. 115 BDS students participated in this study including both male and female students. It is designed to measure the student's feedback about the lecture rooms to improve the effectiveness of the lectures. Lecture room environment plays an important role in the learning process. Learning environment serves as a source of motivation for the students and to attend a long lecture ${ }^{10}$. If the learning environment is not comfortable and satisfactory it has negative effects on the learning and mood of the students, which directly influence their performance ${ }^{11}$. A study conducted in the University of Salford findings showed that learners' performance increased with the well effective classroom ${ }^{12}, 51 \%$ of the improved performance of the students concerning the modified lecture room $^{13}$. As in our study, most of the infrastructure and environment was modified and similar $91 \%$ of the modification. In this study, $100 \%$ of the students were satisfied with the environment, which was also reported by another study that students performed effectively ${ }^{14}$. Ninety-eight percent of students out of 115 considered that lecture room environment positively affected the learning process. Bakhshialiabad et al (2015) suggested that it's the responsibility of the institutional authorities to provide an effective learning environment with required facilities and opportunities for the students ${ }^{15}$. The data obtained from this research will aid in to provide more facilities. The seating design results revealed that $47 \%$ of students need chairs with tables and comfortable chairs. $40 \%$ of students asked for the bench with the tables. Comfort level is directly proportional to productivity. Chairs with tables are easy for the students to write and keep their notebooks. At the time they pay attention to the lecturer and write down the notes. Similarly, the spacing between the chairs will be maintained to avoid disturbances ${ }^{16}$. In this research, $41 \%$ of students reported that they are satisfied with the lecture-room temperature. The researches revealed that the students learn better in the cooler atmosphere ${ }^{17}$. The extreme temperatures distract students from the lectures and raise the hostility in them. The performance of the students is hindered by high temperatures and humidity ${ }^{18}$. The research confirms that most of the facilities are available for the students and some of them are required.

\section{CONCLUSION:}

Infrastructure and environment of the lecture rooms were satisfactory. However, certain domains required further improvements and modifications. This study provides a baseline for further researches in assessing the students' needs and perception regarding the lecture rooms.

\section{REFERENCES:}

1. Shukla RR. A systematic approach for improvement in quality and standard of higher education institution through a feedback system. J Current Sci. 2019;20(2).

2. Alderman L, Towers S, Bannah S. Student feedback systems in higher education: a focused literature review and environmental scan. Qual Higher Educ. 2012;18(3):261-80.

3. Baepler P, Walker JD, Driessen M. It's not about seat time: blending, flipping, and efficiency in active learning classrooms. Computers Edu. 2014;78:227-36.

4. Barrett $P$, Davies F, Zhang Y, Barrett L. The impact of classroom design on pupils' learning: final results of a holistic, multi-level analysis. Building Environ. 2015;89:118-33.

5. Sheffler JL. Creating a warm and inclusive classroom environment: planning for all children to feel welcome. Electronic J Inclusive Educ. 2009;2(4):4.

6. Weimer, M. Effective teaching strategies: six keys to classroom excellence. Faculty Focus. 2009.

7. Zifferblatt SM. Architecture and human behavior: toward increased understanding of a functional relationship. Educ Tech. 1972;12(8):54-7. 
8. Marchand GC, Nardi NM, Reynolds D Pamoukov S. The impact of the classroombuilt environment on student perceptions and learning. J Environ Psych. 2014;40:187-97.

9. Damşa C, Nerland M, Andreadakis ZE. An ecological perspective on learner-constructed learning spaces. British J Educ Tech. 2019.

10. Liljedahl M. Learning in the clinical environment. 2016. The department of learning, informatics, management and ethics. Karolinska Institute, Sweden. ISBN. 978-917676-386-5.

11. Turano AA. The impact of classroom environment on student learning. 2005. Thesis and Dissertation. 1089. Retrieved from https://rdw.rowan.edu/etd/1089

12. Barrett $P$, Zhang $Y$, Moffat J, Kobbacy K. A holistic, multi-level analysis identifying the impact of classroom design on pupils' learning. Building Environ. 2012. doi: 10.1016/j.buildenv.2012.09.016.

13. Barrett $P$, Zhang $Y$, Moffat J, Kobbacy K. A holistic, multi-level analysis identifying the impact of classroom design on pupils' learning. Building Environ. 2013;59:678-89.
14. Henry AT. Med students' perceptions of learning environment matter. 2016. Accelerating change in medical education. Retrieved from https://www.amaassn.org/education/accelerating-changemedical-education/med-studentsperceptions-learning-environment.

15. Bakhshialiabad H, Bakhshi M, Hassanshahi G. Students' perceptions of the academic learning environment in seven medical sciences courses based on DREEM. Adv Med Educ Pract. 2015;6:195-203.

16. Rands ML, Gansemer-Topf AM. The room itself is active: how classroom design impacts student engagement. J Learning Spaces. 2017;6(1):26.

17. Wargocki P, Wyon DP. The effects of moderately raised classroom temperatures and classroom ventilation rate on the performance of schoolwork by children (RP1257). Hvac\&R Res. 2007;13(2):193-220.

18. Mendell MJ, Heath GA. Do indoor pollutants and thermal conditions in schools influence student performance? a critical review of the literature. Indoor Air. 2005;15(1):27-52.

\section{CONTRIBUTORS}

Sofia Shehzad - Drafting Manuscript; Critical Revision; Supervision; Final Approval

Zainab Waheed - Data Acquisition; Data Analysis/Interpretation; Drafting Manuscript; Critical Revision Samir Khan Kabir - Concept \& Design; Data Acquisition; Supervision; Final Approval

Sofia Haider Durrani - Data Acquisition; Critical Revision

Muhammad llyas - Data Acquisition; Critical Revision

Afaq Farooq - Data Acquisition; Drafting Manuscript 